Elżbieta Kremer ${ }^{1}$

\title{
Obrót nieruchomościami z udziałem małżonków
}

\section{Wstęp}

Problematyka obrotu nieruchomościami stanowi fragment ogólnej problematyki prawa rzeczowego, a szerzej ujmując prawa cywilnego i obejmuje uregulowania dotyczące nieruchomości zawarte zarówno w kodeksie cywilnym, jak i w pozakodeksowych przepisach prawa. Rozważając problematykę obrotu nieruchomościami, można uwagę koncentrować na różnych aspektach tej problematyki. Przede wszystkim w zależności od przyjętej konwencji odnośnie do zakresu pojęcia „obrót” rozważania mogą koncentrować się wyłącznie na obrocie własnościowym bądź też przy szerokim rozumieniu tego pojęcia kryterium decydującym może być zmiana osoby władającej nieruchomością. Można również rozważania te prowadzić, mając na uwadze podział na obrót inter vivos i mortis causa. Innym, często stosowanym kryterium, które będzie decydować o zakresie prowadzonych badań, jest kryterium przedmiotowe. To przedmiotowe spojrzenie na pojęcie nieruchomości sprawia, że wyróżniamy, obok obrotu powszechnego, szczególne rozwiązania dotyczące czy to obrotu nieruchomościami rolnymi, leśnymi, czy też nieruchomościami budynkowymi lub lokalowymi. $Z$ punktu widzenia przedmiotowego to zasady dotyczące obrotu nieruchomościami rolnymi stanowiły i stanowią obiekt szczególnego zainteresowania doktryny. Problematyka obrotu nieruchomościami może być również rozważana w aspekcie podmiotowym, w ramach którego można stosować różne kryteria podmiotowe. Jednym z takich możliwych do zastosowania kryteriów podmiotowych jest udział małżonków w obrocie nieruchomościami. To spojrzenie na obrót nieruchomościami w sytuacji, gdy co najmniej jedną ze stron tego obrotu będzie osoba pozostająca w związku małżeńskim lub oboje małżonkowie, będzie przedmiotem dalszych rozważań.

Kryterium podmiotowe ujęte ogólnie jako udział małżonków w obrocie nieruchomościami jest tym kryterium podstawowym, wokół którego będzie koncentrować się rozważana problematyka. Takie ujęcie przedmiotu rozważań pozwoli za- 
równo wskazać na szczególne rozwiązania dotyczące obrotu nieruchomościami, których powodem wprowadzenia jest fakt, że w obrocie uczestniczą małżonkowie, jak również pozwoli na ocenę istniejących rozwiązań i podjęcie próby sformułowania ogólnych wniosków.

Uczynienie przedmiotem rozważań problematyki obrotu nieruchomościami z udziałem małżonków sprawia, że w pierwszej kolejności należy sięgnąć do rozwiązań prawnych regulujących małżeńskie ustroje majątkowe, aby zbadać, jak fakt zawarcia małżeństwa i wybór określonego ustroju majątkowego wpływa na sytuację prawną małżonków.

Warto zaznaczyć, że na przestrzeni wieków regulacje prawne dotyczące małżeńskich stosunków majątkowych stanowią szczególnie obszerną i ciekawą część historii prawa i to zarówno w ramach historii prawa polskiego, jak i powszechnego. Ta różnorodność i wielość rozwiązań, jakie pojawiały się na przestrzeni wieków, począwszy od prawa antycznego do czasów nowożytnych, prowadzi do kilku ogólnych wniosków: przede wszystkim funkcjonujące we współczesnym porządku prawnym modele małżeńskich ustrojów majątkowych nie zawsze są nowatorskimi rozwiązaniami, ale często rozwiązaniami, które występowały już w historii. Ponadto katalog obowiązujących prawnych modeli małżeńskich stosunków majątkowych jest obecnie znacznie skromniejszy, niż to niejednokrotnie na przestrzeni wieków bywało, a nadto na sposób uregulowania stosunków majątkowych między małżonkami istotny wpływ mają regulacje dotyczące małżeńskich stosunków osobowych, które z kolei są odzwierciedleniem stosunków społecznych. W obowiązującym stanie prawnym rozwiązania dotyczące małżeńskich ustrojów majątkowych są niewątpliwie decydującym czynnikiem, który kształtuje sytuację prawną małżonków w obrocie nieruchomościami.

\section{Ustawowy ustrój majątkowy}

W Polsce ustawowy ustrój majątkowy, jakim jest wspólność majątkowa małżeńska, pozostaje nadal podstawowym, najczęściej występującym w praktyce ustrojem majątkowym. W ustroju wspólności ustawowej małżonków wyodrębnia się trzy masy majątkowe: majątek wspólny, majątek osobisty męża, majątek osobisty żony. W tym ustroju majątkowym istotną rolę odgrywają dwa zagadnienia: pierwsze zagadnienie to określenie zasad, w oparciu o które powstaje majątek wspólny małżonków, a więc określenie z punktu widzenia przedmiotowego, co tworzy ten majątek, a drugie zagadnienie związane jest z przyjętymi zasadami dotyczącymi zarządu majątkiem wspólnym. Jak wynika z przepisu art. 31 § 1 k.r.o., wspólność majątkowa (wspólność ustawowa) obejmuje przedmioty majątkowe nabyte w czasie jej trwania przez oboje małżonków lub przez jednego z nich (majątek wspólny). Natomiast art. $31 \S 2$ k.r.o. wskazuje, że do majątku wspólnego należą w szczególności: pobrane 
wynagrodzenie za pracę i dochody z innej działalności zarobkowej każdego z małżonków, dochody z majątku wspólnego, jak również z majątku osobistego każdego z małżonków, środki zgromadzone na rachunku otwartego lub pracowniczego funduszu emerytalnego każdego z małżonków. Przedmioty majątkowe nieobjęte wspólnością ustawową należą do majątku osobistego każdego z małżonków. Tym drugim istotnym zagadnieniem jest regulacja dotycząca zasad zarządu majątkiem wspólnym. To zasady dotyczące zarządu majątkiem wspólnym kształtują sytuację prawną małżonków w obrocie nieruchomościami należącymi do majątku wspólnego. Pierwszą fundamentalną zasadą charakteryzującą zarząd majątkiem wspólnym jest zasada samodzielnego zarządu majątkiem wspólnym przez małżonków. Zasada ta została wyłączona w dwóch przypadkach. Pierwszy przypadek dotyczy sytuacji, gdy przedmioty majątkowe należą do majątku wspólnego, ale służą jednemu małżonkowi do wykonywania zawodu lub prowadzenia działalności zarobkowej, wówczas małżonek ten zarządza nimi samodzielnie. ${ }^{2}$ Drugi przypadek, w którym została wyłączona zasada samodzielnego zarządu majątkiem wspólnym, został określony w przepisie art. $37 \S 1$ k.r.o. i obejmuje cztery enumeratywnie wymienione sytuacje, w których potrzebna jest zgoda drugiego małżonka.

\section{Czynności prawne wymagające zgody współmałżonka}

Zgoda drugiego małżonka jest potrzebna do dokonania:

1) czynności prawnej prowadzącej do zbycia, obciążenia, odpłatnego nabycia nieruchomości lub użytkowania wieczystego, jak również prowadzącej do oddania nieruchomości lub używania lub pobierania z niej pożytków,

2) czynności prawnej prowadzącej do zbycia, obciążenia, odpłatnego nabycia prawa rzeczowego, którego przedmiotem jest budynek lub lokal,

3) czynności prawnej prowadzącej do zbycia, obciążenia, odpłatnego nabycia i wydzierżawienia gospodarstwa rolnego lub przedsiębiorstwa,

4) darowizny z majątku wspólnego, z wyjątkiem drobnych darowizn zwyczajowo przyjętych.

Jeżeli w powyższych przypadkach doszło do zawarcia umowy przez jednego z małżonków bez wymaganej zgody drugiego, ważność umowy zależy od potwierdzenia umowy przez drugiego małżonka. W takiej sytuacji dokonana czynność pozostanie w stanie bezskuteczności zawieszonej, dopóki kontrahent małżonka działającego nie wyznaczy drugiemu małżonkowi terminu do potwierdzenia dokonanej czynności. Wyznaczenie małżonkowi, którego zgoda jest wymagana, odpowiedniego terminu do potwierdzenia umowy powoduje, że po bezskutecznym upływie tego 
terminu kontrahent staje się wolny. ${ }^{3}$ Natomiast jednostronna czynność dokonana bez wymaganej zgody drugiego małżonka jest nieważna. ${ }^{4}$

Przyjęty przez ustawodawcę model sprawowania zarządu majątkiem wspólnym przez małżonków, a precyzyjnie mówiąc poszczególne rozwiązania zawarte w tym modelu są jednak obarczone wątpliwościami wynikającymi czy to ze słuszności przyjętych założeń, czy też niedoskonałości legislacyjnych lub systemowych. Powyższe wątpliwości dotyczą przede wszystkim sposobu określenia czynności prawnych, dla dokonania których potrzebna jest zgoda drugiego małżonka. Spróbujmy zatem przyjrzeć się bliżej tym sytuacjom, w których zgoda drugiego małżonka jest konieczna.

Pierwsze spostrzeżenie, jakie się nasuwa, dotyczy określenia przedmiotów czynności prawnych, dla dokonania których potrzebna jest zgoda drugiego małżonka. Generalnie wymóg ten ustawodawca łączy z czynnościami prawnymi, których przedmiotem są nieruchomości, w tym również nieruchomości budynkowe i lokalowe, jak również pewne kompleksy majątkowe, takie jak: przedsiębiorstwo i gospodarstwo rolne (jedynie w przypadku darowizny z majątku wspólnego przedmiot darowizny nie został ograniczony). Tym samym ustawodawca przyjmuje, że należące do majątku wspólnego małżonków: nieruchomości, przedsiębiorstwo, gospodarstwo rolne pełnią szczególną rolę dla zabezpieczenia i funkcjonowania rodziny, a to uzasadnia wyłączenie zasady samodzielnego zarządu majątkiem wspólnym przez małżonków. To wyłączenie zasady samodzielnego zarządu majątkiem wspólnym ma miejsce w każdym przypadku bez względu na wielkość i wartość nieruchomości, jak również bez względu na wartość nieruchomości w stosunku do całego majątku wspólnego. Natomiast zasada samodzielnego zarządu majątkiem wspólnym nie jest wyłączona w sytuacji, gdy przedmiotem czynności prawnych są rzeczy ruchome lub inne prawa i to bez względu na ich wartość. W regulacji tej dostrzegamy zatem bardzo tradycyjny sposób oceny rzeczywistości, w której nieruchomości nadal są postrzegane jako najbardziej wartościowe i istotne składniki majątku wspólnego małżonków. W konsekwencji jeden z małżonków zgodnie z zasadą samodzielnego zarządu majątkiem wspólnym może zbyć rzecz ruchomą o znacznej wartości bez zgody drugiego małżonka, natomiast w przypadku zbycia jakiejkolwiek nieruchomości bez względu na jej wartość zgoda drugiego małżonka jest konieczna.

Drugie spostrzeżenie dotyczy sposobu uregulowania zakresu czynności prawnych, do dokonania których w myśl w art. 37 § 1 k.r.o. potrzebna jest zgoda drugiego małżonka. Generalnie zgoda drugiego małżonka jest potrzebna do dokonania czynności prawnej prowadzącej do zbycia, obciążenia, odpłatnego nabycia prawa

Art. 37 § 2 i 3 Kodeksu rodzinnego i opiekuńczego w brzmieniu nadanym ustawą z dnia 17.06.2004 r. Dz.U. Nr 162, poz. 1691.

$4 \quad$ Art. 37 § 4 Kodeksu rodzinnego i opiekuńczego w brzmieniu nadanym ustawą z dnia 17.06.2004 r. Dz.U. Nr 162, poz. 1691. 
własności, prawa użytkowania wieczystego nieruchomości, do dokonania czynności prowadzącej do oddania nieruchomości do używania lub pobierania z niej pożytków, jak również do wydzierżawienia gospodarstwa rolnego lub przedsiębiorstwa. Tak określony przez ustawodawcę zakres czynności rodzi pewne wątpliwości. Pierwsza wątpliwość dotyczy relacji pomiędzy pojęciem czynności prawnej prowadzącej do obciążenia a oddaniem nieruchomości do używania, pobierania z niej pożytków, czy też wydzierżawienia gospodarstwa lub przedsiębiorstwa. Jak podkreśla się w literaturze, ${ }^{5}$ ostatnie z wymienionych czynności prowadzą przecież do jednoczesnego obciążenia prawa własności nieruchomości, a taka czynność już wymaga zgody drugiego małżonka. Stąd też pojawia się wątpliwość, jak rozumieć zakres pojęcia „czynności prawne”, które prowadzą do obciążenia nieruchomości, czy w zakresie tego pojęcia mieszczą się wyłącznie obciążenia nieruchomości mające charakter ograniczonych praw rzeczowych, czy również inne obciążenia o charakterze obligacyjnym. Problem ten dodatkowo komplikuje się, zważywszy na niejasną treść art. $37 \S 1$ pkt 2, w którym jest mowa o czynności prawnej prowadzącej do zbycia, obciążenia, odpłatnego nabycia prawa rzeczowego, którego przedmiotem jest budynek lub lokal. Określenie wzajemnych relacji pomiędzy zakresem pkt 1 i pkt 2 jest jednym $\mathrm{z}$ istotnych spornych zagadnień. Jednym z proponowanych rozwiązań jest stanowisko, zgodnie z którym art. 37 § 1 pkt 1 k.r.o. dotyczy nieruchomości gruntowych i w tym przypadku zakres czynności wymagających zgody drugiego małżonka jest szerszy i obejmuje nie tylko czynności prawnorzeczowe, ale także niektóre czynności obligacyjne. Natomiast art. $37 \S 1$ pkt 2 k.r.o. dotyczy nieruchomości budynkowych i lokalowych, co do tych nieruchomości zgoda drugiego małżonka jest potrzebna w przypadku dokonywania czynności prawnorzeczowych. ${ }^{6}$ Nadto przyjęta konstrukcja sprawowania zarządu majątkiem wspólnym wymaga uzyskania zgody drugiego małżonka w przypadku czynności prawnej prowadzącej do zbycia, obciążenia, odpłatnego nabycia i wydzierżawienia gospodarstwa rolnego lub przedsiębiorstwa. Na tle tego rozwiązania, podkreślić przede wszystkim należy, że z samego faktu, że w skład majątku wspólnego małżonków wchodzi gospodarstwo rolne (przedsiębiorstwo), nie została wykluczona podstawowa zasada jaką jest zasada, samodzielnego zarządu majątkiem wspólnym przez każdego z małżonków, jak również nie została wyłączona zasada nakładająca obowiązek współdziałania małżonków w zarządzie majątkiem wspólnym. Natomiast zasada samodzielnego zarządu majątkiem wspólnym została ograniczona poprzez konieczność uzyskania zgody drugiego małżonka w przypadku dokonywania czynności prawnej prowadzącej do zbycia, obciążenia, odpłatnego nabycia, wydzierżawienia gospodarstwa rolnego (przedsiębiorstwa). Przepisy kodeksu rodzinnego dotyczące małżeńskich ustromajatkowego (cz. I) „Rejent” 2004, nr 8, s.156. 
jów majątkowych nie definiują zarówno pojęcia gospodarstwa rolnego, jak i pojęcia przedsiębiorstwa, ani nie odsyłają do innych regulacji, które takie definicje posiadają. W takiej sytuacji trzeba sięgnąc do ogólnych rozwiązań dotyczących pojęcia gospodarstwa rolnego (art. $55^{3} \mathrm{kc}$.), pojęcia przedsiębiorstwa (art. $55^{1} \mathrm{kc}$.), które zawarte są w części ogólnej kodeksu cywilnego. Wątpliwości powstają, gdy porównamy regulację kodeksu cywilnego dotyczącą gospodarstwa rolnego i przedsiębiorstwa. Mianowicie ustawodawca, wprowadzając do kodeksu cywilnego definicję przedsiębiorstwa, nie ograniczył się tylko do samej definicji tak jak przy gospodarstwie rolnym, ale wprowadził zasadę, że czynność prawna mająca za przedmiot przedsiębiorstwo obejmuje wszystko, co wchodzi w skład przedsiębiorstwa (chyba że co innego wynika z treści czynności prawnej albo przepisów szczególnych). ${ }^{7}$ Kolejna różnica dotyczy szczególnej regulacji dotyczącej formy czynności prawnej w przypadku zbycia lub wydzierżawienia przedsiębiorstwa albo ustanowienia na nim użytkowania. Przepis art. $75^{1} \mathrm{kc}$. wprowadza wymóg formy pisemnej z podpisami notarialnie poświadczonymi, a także wpis do rejestru, jeżeli przedsiębiorstwo należy do osoby wpisanej do rejestru. ${ }^{8}$ Konsekwencją tego zróżnicowanego stanu prawnego dotyczącego gospodarstwa rolnego i przedsiębiorstwa jest dopuszczenie możliwości obrotu przedsiębiorstwem na podstawie jednej czynności prawnej. Natomiast inną sytuację mamy w przypadku gospodarstwa rolnego, którego status prawny jest odmienny. Stanowiska przedstawicieli doktryny są w tej kwestii podzielone. Dominuje pogląd, że de lege lata gospodarstwo rolne jako całość nie jest przedmiotem prawa i w tym charakterze (jako całość) nie może być przedmiotem czynności prawnej. W konsekwencji, w przypadku np. umowy sprzedaży gospodarstwa rolnego, przedmiotem przeniesienia własności nie jest ogół składników materialnych składających na całość gospodarczą, jaką jest gospodarstwo rolne, lecz każdy z tych składników z osobna. ${ }^{9} \mathrm{~A} w$ konsekwencji, należy stwierdzić, że wbrew literalnemu brzmieniu art. $37 \S 1$ pkt 3 k.r.o. małżonek, z przyczyn, o których była mowa wyżej, nie wyraża zgody na zbycie, obciążenie, odpłatne nabycie i wydzierżawienie gospodarstwa rolnego jako całości, lecz na poszczególne składniki gospodarstwa rolnego będące przedmiotem czynności prawnej. ${ }^{10}$

Z powyższych zasad wynika, że w sytuacji, gdy przedmiotem obrotu jest nieruchomość należąca do majątku wspólnego małżonków, ograniczona została zasada samodzielnego zarządu majątkiem wspólnym przez jednego z małżonków poprzez wymóg uzyskania zgody drugiego małżonka do dokonania danej czynności prawnej. Można zauważyć, że bez względu na to, czy jest to nieruchomość lokalowa, budynkowa czy gruntowa, jak również niezależnie od charakteru nieruchomości grun-

$7 \quad$ Art. $75^{1} \mathrm{kc}$.

8 Przepisy powyższe nie uchybiają przepisom o formie czynności prawnych dotyczących nieruchomości - art. 75 $1 \S 4 \mathrm{kc}$.

$9 \quad$ E. Kremer, op. cit., s. 38 I 39 oraz cytowana tam literatura.

10 J. Ignaczewski, Małżeńskie ustroje majątkowe Art. 31-54 KRO. Komentarz, Warszawa 2008, s. 98. 
towej, w każdym przypadku zbycia bądź obciążenia takiej nieruchomości konieczna jest zgoda drugiego małżonka. A zatem, niezależnie od rodzaju czynności prawnej, niezależnie od jej odpłatnego bądź nieodpłatnego charakteru prawnego, jeżeli czynność ta będzie prowadzić do zbycia nieruchomości należącej do majątku wspólnego małżonków, bądź będzie prowadzić do jej obciążenia poprzez ustanowienie ograniczonego prawa rzeczowego, konieczne jest zgodne działanie małżonków. Natomiast w przypadku, gdy nieruchomość należąca do majątku wspólnego małżonków ma być przedmiotem czynności prawnych o charakterze obligacyjnym, wówczas wymóg uzyskania zgody drugiego małżonka został różnie określony w zależności od rodzaju nieruchomości. W przypadku nieruchomości gruntowych zgoda drugiego małżonka jest konieczna dla dokonania czynności prawnej prowadzącej do oddania nieruchomości do używania lub pobierania z niej pożytków. W przypadku nieruchomości budynkowych lub lokalowych dla zawarcia czynności prawnych o charakterze obligacyjnym zgoda drugiego małżonka nie jest potrzebna, w przypadku zaś gospodarstwa rolnego lub przedsiębiorstwa zgoda drugiego małżonka jest potrzebna dla wydzierżawienia gospodarstwa lub przedsiębiorstwa. Zgoda drugiego małżonka jest potrzebna nie tylko w przypadku zbycia lub obciążenia nieruchomości należącej do majątku wspólnego małżonków, ale również w przypadku odpłatnego nabycia nieruchomości do majątku wspólnego. Jeżeli nabycie nieruchomości do majątku wspólnego ma nastąpić na podstawie nieodpłatnej czynności prawnej, wówczas zgoda drugiego małżonka nie jest potrzebna. Tym samym obrót nieruchomościami stanowiącymi majątek wspólny małżonków może być dokonany, gdy stroną czynności prawnej będą oboje małżonkowie, a w przypadku, gdy stroną czynności prawnej ma być jeden z małżonków, wówczas koniecznym jest uzyskanie zgody drugiego małżonka.

\section{Ingerencja sądu w zarząd majątkiem wspólnym}

Przyjęta konstrukcja dotycząca majątku wspólnego małżonków i zasady zarządu tym majątkiem, z których wynika wymóg uzyskania zgody drugiego małżonka dla dokonania określonych czynności prawnych, skłania do rozważania takiej sytuacji, gdy wymaganej zgody drugiego małżonka nie można uzyskać.

W takich okolicznościach, gdy jeden z małżonków odmawia wyrażenia zgody wymaganej do dokonania czynności, albo jeżeli porozumienie z nim napotyka trudne do przezwyciężenia przeszkody, drugi małżonek może zwrócić się do sądu o zezwolenie na dokonanie czynności, a sąd udziela zezwolenia, jeżeli dokonania czynności wymaga dobro rodziny. ${ }^{11}$ Sąd może również postanowić, z ważnych powodów na żądanie jednego z małżonków, że na dokonanie czynności, o których mowa 
w art. $37 \S 1$ zamiast zgody małżonka będzie potrzebne zezwolenie sądu. ${ }^{12}$ Tym samym, w przypadku braku możliwości uzyskania zgody drugiego małżonka czy to z przyczyn obiektywnych, czy też z uwagi na istniejący spór między małżonkami, orzeczenie sądu zezwalające na dokonanie określonej czynności prawnej zastąpi brakującą zgodę drugiego małżonka. Należy podkreślić, iż sąd, udzielając zezwolenia na dokonanie określonej czynności prawnej, winien kierować się jednym kryterium, jakim jest dobro rodziny. Zezwolenie sądu dotyczy czynności prawnej, która ma być dokonana w przyszłości. Natomiast zezwolenia sądu nie można utożsamiać z jakimś szczególnym trybem zatwierdzania przez sąd umowy zawartej uprzednio bez zgody współmałżonka. ${ }^{13}$ Poza wskazanym wyżej trybem udzielenia zezwolenia przez sąd, który dotyczy jednostkowej czynności prawnej, sąd z ważnych powodów na żądanie jednego z małżonków może zmienić zasady zarządu majątkiem wspólnym. Kompetencje sądu w zakresie modyfikacji zasad zarządu majątkiem wspólnym mogą być następujące: pozbawienie jednego z małżonków samodzielnego zarządu całym majątkiem wspólnym lub określonymi składnikami, postanowienie, że na dokonanie czynności wskazanych w art. 37 § 1 zamiast zgody małżonka będzie potrzebne zezwolenie sądu. W tych przypadkach modyfikacja zasad zarządu majątkiem wspólnym ma charakter generalny i odnosi się na przyszłość do wszystkich czynności prawnych podejmowanych przez małżonków po uprawomocnieniu się orzeczenia sądu. ${ }^{14}$

\section{Umowne ustroje majątkowe}

W ramach umownych ustrojów majątkowych małżonkowie mogą drogą umowy zawartej w formie aktu notarialnego rozszerzyć wspólność ustawową lub ograniczyć albo ustanowić rozdzielność majątkową lub rozdzielność majątkową z wyrównaniem dorobków. W umownym ustroju wspólności majątkowej małżonkowie ,zachowując co do zasady wspólnotę majątkową, mogą w granicach wskazanych przez prawo wspólność ustawową rozszerzyć lub ograniczyć. Stwierdzenie to odnosi się do zmiany przynależności konkretnych praw i przedmiotów majątkowych, tzn mogą określone prawo, które według ustawowych zasad przynależy do majątku wspólnego, włączyć do majątku osobistego i odwrotnie. ${ }^{15}$ Ustawodawca wskazal, aby do ustanowionej umową wspólności majątkowej stosować odpowiednio przepisy o wspólności ustawowej. Z powyższego odesłania wynika, że zasady dotyczące sprawowania zarządu majątkiem wspólnym w umownym ustroju majątkowym są analogiczne jak w przypadku majątku wspólnego w ustawowym ustroju majątkowym. Można zatem stwierdzić, że zarówno w ustawowym ustroju wspólności ma-

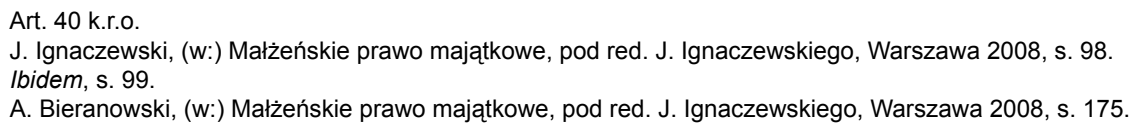


jątkowej, jak i w umownym ustroju wspólności majątkowej pozycja prawna małżonków w obrocie nieruchomościami ukształtowana jest według tych samych zasad.

$\mathrm{Z}$ kolei w umownych ustrojach: rozdzielności majątkowej i rozdzielności majątkowej z wyrównaniem dorobków, każdy z małżonków zachowuje zarówno majątek nabyty przed zawarciem umowy, jak i majątek nabyty później. W tych ustrojach majątkowych nie powstaje majątek wspólny małżonków. Natomiast fundamentalną zasadą tych ustrojów jest, że każdy z małżonków zarządza samodzielnie swoim majątkiem. Ta zasada jest zachowana również w sytuacji, gdy przedmiotem obrotu jest nieruchomość należąca do majątku osobistego jednego z małżonków. Tym samym fakt pozostawania $\mathrm{w}$ związku małżeńskim nie wpływa na sytuację prawną małżonka w zakresie podejmowania czynności prawnych mających na celu zbycie, obciążenie lub odpłatne nabycie nieruchomości.

\section{Rozwiązania szczególne dotyczące obrotu nieruchomościami z udziałem małżonków}

Taką regulacją szczególną jest ustawa z dnia 11 kwietnia 2003 r. o kształtowaniu ustroju rolnego. ${ }^{16}$ Koniecznym staje się zatem spojrzenie na rozwiązania szczególne z uwzględnieniem zasad dotyczących sprawowania zarządu majątkiem wspólnym małżonków. Dopiero konfrontacja tych dwóch ustawowych rozwiązań pozwoli w pełni zobaczyć, jak kształtuje się sytuacja prawna małżonków sprawujących zarząd majątkiem wspólnym, w którego skład wchodzi nieruchomość rolna. Oczywiście konfrontacja ta może dotyczyć tylko tych zagadnień, które są przedmiotem regulacji w obu ustawach, tj. kodeksie rodzinnym i opiekuńczym oraz w ustawie o kształtowaniu ustroju rolnego. Tym zakresem wspólnym jest problematyka dotycząca przeniesienia na podstawie umowy własności nieruchomości rolnej stanowiącej majątek wspólny małżonków lub nabycie przez małżonków prawa własności nieruchomości rolnej do majątku wspólnego. Mimo że problematyka ta jest przedmiotem regulacji zarówno kodeksu rodzinnego, jak i ustawy o kształtowaniu ustroju rolnego, to jednak każda z tych regulacji kładzie nacisk na właściwą dla siebie tematykę. Z punktu widzenia zasad sprawowania zarządu majątkiem wspólnym przez małżonków szczególnie istotne są te czynności prawne, które prowadzą do zbycia czy obciążenia prawa własności nieruchomości należącej do majątku wspólnego, stąd też wymóg uzyskania zgody drugiego małżonka. Wymóg uzyskania zgody dotyczy każdej nieruchomości, w tym również nieruchomości rolnej i to bez względu na to, czy nieruchomość ta wchodzi w skład gospodarstwa rolnego, czy też nie. Ten wymóg zgodnego działania małżonków w sytuacji, gdy w wyniku czynności prawnej ma dojść do zbycia prawa własności nieruchomości wchodzącej w skład majątku wspólnego, powodowany jest wyłącznie potrzebą ochrony, zabezpieczenia

Dz.U. Nr 64, poz. 592. 
interesów majątkowych rodziny. Natomiast fakt, że przedmiotem zbycia jest nieruchomość rolna z punktu widzenia zbywców, nie ma prawnego znaczenia. Również ustawa o kształtowaniu ustroju rolnego wprowadzająca szczególne zasady obrotu nieruchomościami rolnymi nie wprowadza żadnych szczególnych wymogów, które musiałyby być spełnione przez zbywcę nieruchomości rolnej.

Natomiast odmienną sytuację prawną mamy w przypadku, gdy nabywana w drodze czynności prawnej nieruchomość rolna ma wejść do majątku wspólnego małżonków. Z punktu widzenia zasad sprawowania zarządu majątkiem wspólnym zgoda małżonków jest potrzebna, gdy nabycie ma odpłatny charakter. W przypadku, gdy nabycie nieruchomości rolnej do majątku wspólnego małżonków ma nastąpić na podstawie czynności prawnej o charakterze nieodpłatnym, zgoda drugiego małżonka nie jest potrzebna. Czyli dla określenia wymogów nabycia przez małżonków nieruchomości do majątku wspólnego z punktu widzenia zasad sprawowania zarządu elementem decydującym jest odpłatny lub nieodpłatny charakter czynności prawnej, natomiast prawnie irrelewantne jest, czy nabywana nieruchomość jest nieruchomością rolną, czy też nie ma charakteru rolnego. Z kolei to, czy przedmiotem czynności prawnej prowadzącej do nabycia nieruchomości jest nieruchomość rolna, czy też nieruchomość, która nie ma takiego charakteru, istotne jest z punktu widzenia szczególnych zasad określonych w ustawie o kształtowaniu ustroju. Te szczególne zasady mogą bowiem spowodować, iż zamierzona transakcja nabycia własności nieruchomości rolnej nie dojdzie do skutku. Ustawodawca wyposażył bowiem Agencję Nieruchomości Rolnych w prawo pierwokupu ${ }^{17}$ nieruchomości rolnej w przypadku sprzedaży lub w prawo nabycia, ${ }^{18}$ jeżeli przeniesienie własności nieruchomości rolnej następuje w wyniku zawarcia umowy innej niż umowa sprzedaży. Uprawnienia te nie przysługują Agencji Nieruchomości Rolnej m.in. wtedy, gdy w wyniku nabycia własności nieruchomości rolnej następuje powiększenie gospodarstwa rodzinnego. Ustawodawca określił, że za gospodarstwo rodzinne ${ }^{19}$ uważa się gospodarstwo rolne prowadzone przez rolnika indywidualnego, w którym łączna powierzchnia użytków rolnych jest nie większa niż 300 ha. Zawarto również definicję rolnika indywidualnego ${ }^{20}$ którym jest osoba fizyczna będąca właścicielem, użytkownikiem wieczystym, samoistnym posiadaczem lub dzierżawcą nieruchomości rolnych, prowadząca osobiście gospodarstwo rolne (tzn. pracująca w tym gospodarstwie i podejmująca wszelkie decyzje dotyczące prowadzenia działalności rolniczej w tym gospodarstwie), posiadająca kwalifikacje rolnicze, zamieszkała w gminie, na obszarze której położona jest jedna z nieruchomości rolnych wchodzących w skład gospodarstwa rolnego i prowadząca przez ten okres osobiście to gospodarstwo. Tym samym zupełnie zostały pominięte te sytuacje, gdy gospodarstwo rolne prowadzone jest 
przez małżonków, pomiędzy którymi istnieje wspólność ustawowa. Stąd też pojawia się zasadnicze pytanie, jakie muszą być spełnione przesłanki, aby gospodarstwo rolne prowadzone przez małżonków można było uznać za gospodarstwo rodzinne. ${ }^{21}$ Czy kryteria wymagane dla uzyskania statusu rolnika indywidualnego muszą spełniać oboje małżonkowie, czy wystarczy, że spełnia je jeden z nich. Sąd Najwyższy w wyroku z dnia 29 stycznia 2008 r. sformułował pogląd, zgodnie z którym, jeżeli gospodarstwo rolne prowadzone jest przez małżonków, to dla uznania tego gospodarstwa za rodzinne nie jest konieczne, aby kwalifikacje rolnicze posiadali oboje małżonkowie. Wystarczające zatem jest, aby kwalifikacjami rolniczymi legitymował się ten z małżonków, który faktycznie podejmuje decyzje w procesie gospodarowania. ${ }^{22}$ Jak zatem kształtuje się sytuacja prawna małżonków, jeżeli w wyniku czynności prawnej mają nabyć do majątku wspólnego prawo własności nieruchomości rolnej i to zarówno z punktu widzenia przepisów dotyczących ustawowego ustroju majątkowego, jak i ustawy o kształtowaniu ustroju rolnego.

$\mathrm{Z}$ punktu widzenia ustawowego ustroju majątkowego elementem decydującym o sytuacji prawnej małżonków jest odpłatny lub nieodpłatny charakter czynności prawnej. Mianowicie jeżeli czynność prawna prowadząca do nabycia prawa własności nieruchomości rolnej ma charakter odpłatny, wówczas do jej dokonania potrzebna jest zgoda obojga małżonków; jeżeli zaś czynność prawna ma charakter nieodpłatny, wówczas każdy z małżonków może samodzielnie jej dokonać. To kryterium przyjęte przez ustawodawcę jest o tyle niepełne, iż pozwala małżonkowi samodzielnie działającemu na nabycie do majątku wspólnego w drodze co prawda nieodpłatnej czynności prawnej prawa własności nieruchomości, ale np. znacznie obciążonej.

Z kolei z punktu widzenia przepisów ustawy o kształtowaniu ustroju rolnego dla możliwości nabycia przez małżonków do majątku wspólnego prawa własności nieruchomości rolnej nie ma prawnego znaczenia, czy zamierzona czynność prawna będzie miała odpłatny lub nieodpłatny charakter. Natomiast kwestią istotną może okazać się okoliczność, czy w wyniku przeniesienia własności nieruchomości rolnej nastąpi powiększenie gospodarstwa rodzinnego, bo wówczas wyłączone są szczególne uprawnienia Agencji Nieruchomości Rolnej w postaci prawa pierwokupu i prawa nabycia. I tutaj napotykamy na podnoszone wcześniej trudności związane z nieprzystosowaniem prawnej definicji gospodarstwa rodzinnego do sytuacji, gdy prowadzący gospodarstwo rolne pozostaje w związku małżeńskim.

Rozwiązania zawarte w ustawie o kształtowaniu ustroju rolnego z jednej strony wskazują, że o sytuacji prawnej małżonków w obrocie nieruchomościami decydują nie tylko zasady dotyczące małżeńskich ustrojów majątkowych, a z drugiej zaś 
strony pokazują problemy związane z ustaleniem wzajemnej relacji tych regulacji prawnych.

\section{Rozwiązania szczególne o charakterze publicznoprawnym dotyczące obrotu nieruchomościami z udziałem małżonków}

Rozważając sytuację prawną małżonków w obrocie nieruchomościami, można zatem sformułować wniosek, że tym elementem decydującym nie jest sam fakt zawarcia małżeństwa, ale ustrój majątkowy, jaki obowiązuje miedzy małżonkami. Małżonkowie mogą bowiem tak ukształtować stosunki majątkowe między sobą, że zachowają pełną samodzielność w podejmowaniu czynności prawnych dotyczących zbycia, obciążenia, odpłatnego nabycia nieruchomości.

Równocześnie jednak pojawiają się różne regulacje ustawowe dotyczące różnorodnej materii publicznoprawnej, w których sytuacja prawna małżonków kształtowana jest w sposób szczególny, jakby niezależny od istniejącego między nimi ustroju majątkowego. Zgodnie z art. 12 ust 4 i 6 ustawy z dnia 18 grudnia 2003 r. o krajowym systemie ewidencji producentów, ewidencji gospodarstw rolnych oraz ewidencji wniosków o płatności ${ }^{23}$, do ewidencji producentów w przypadku małżonków może być wpisany tylko jeden z małżonków, za pisemną zgodą drugiego małżonka. Z kolei w przypadku regulacji dotyczącej rent strukturalnych ${ }^{24}$ jedną z wymaganych przesłanek dla nabycia renty strukturalnej jest przekazanie gospodarstwa rolnego. Wymagany warunek przekazania jest spełniony wówczas, gdy zostały przekazane wszystkie użytki rolne wchodzące w skład gospodarstwa, będące zarówno przedmiotem odrębnej własności rolnika i jego małżonka, jak również ich współwłasności. Innym przykładem jest rozwiązanie dotyczące pomocy finansowej w ramach działania „Ułatwianie startu młodym rolnikom” ${ }^{25}$, zgodnie z $§ 2$ ust. 6 , jeżeli o pomoc ubiegają się oboje małżonkowie i oboje spełniają warunki jej przyznania, pomoc przyznaje się tylko jednemu z nich, co do którego współmałżonek wyraził pisemną zgodę.

Podobnej natury rozwiązania można odnaleźć w ustawie dotyczącej ubezpieczeń społecznych ${ }^{26}$. Mianowicie zgodnie z art. 28 ust. 4 uznaje się, że emeryt lub rencista zaprzestał prowadzenia działalności rolniczej, jeżeli ani on, ani jego małżonek nie jest właścicielem (współwłaścicielem) lub posiadaczem gospodarstwa rolnego w rozumieniu przepisów o podatku rolnym.

Dz.U. z 2004 r. Nr 10, poz. 76 ze zm.

§ 6 rozporządzenia Ministra Rolnictwa i Rozwoju Wsi z dnia 19 czerwca 2007 r. w sprawie szczegółowych warunków i trybu przyznawania pomocy finansowej w ramach działania „Renty strukturalne” objętego Programem Rozwoju Obszarów Wiejskich na lata 2007-2013, Dz.U. Nr 109, poz. 750 ze zm.

$\S 2$ ust. 6 rozporządzenia Ministra Rolnictwa i Rozwoju Wsi z dnia 17 października 2007 r. w sprawie szczegółowych warunków i trybu przyznawania pomocy finansowej w ramach działania „Ułatwianie startu młodym rolnikom" objętego Programem Rozwoju Obszarów Wiejskich na lata 2007-2013, Dz.U. Nr 200, poz. 1443 ze zm. Ustawa z 20 grudnia 1990 r. o ubezpieczeniu społecznym rolników Dz.U. z 2008 r. Nr 50, poz. 291 ze zm. 
Wskazane przykładowo różne rozwiązania prawne dotyczące małżonków charakteryzują się wspólną cechą. Tą cechą jest konieczność uzyskania zgody małżonka czy to na wpis do ewidencji producentów drugiego małżonka, czy na uzyskanie wsparcia dla młodych rolników przez drugiego małżonka. W przypadku zaś starań przez jednego z małżonków o świadczenia emerytalne lub o rentę strukturalną drugi małżonek musi się wyzbyć będących przedmiotem jego majątku osobistego użytków rolnych. Powyższe rozwiązania mają zastosowanie do wszystkich małżonków niezależnie od ustroju majątkowego, jaki między nimi obowiązuje. Wskazane regulacje prawne dotyczą sfery stosunków publicznoprawnych. W ramach regulacji tych stosunków zwrócono uwagę na szczególną grupę adresatów tych stosunków, jaką są małżonkowie, czyniąc małżeństwo jedynym kryterium wyodrębnienia tej grupy. Jeżeli zatem osoba pozostająca $\mathrm{w}$ związku małżeńskim chce podjąć określone starania, celem których ma być wpis do ewidencji producentów, wsparcie dla młodego rolnika, uzyskanie renty strukturalnej, czy świadczenia emerytalnego, konieczne jest współdziałanie drugiego małżonka w formie udzielenia zgody lub podjęcia czynności prowadzących do zbycia nieruchomości będących przedmiotem jego majątku osobistego. Bez tego zgodnego współdziałania małżonków powyższe cele nie będą mogły być zrealizowane.

\section{Wnioski końcowe}

Dostrzegamy zatem, że problematyka obrotu nieruchomościami w sytuacji, gdy uczestnikami tego obrotu są małżonkowie, jest istotnym, żeby nie rzec podstawowym, zagadnieniem małżeńskiego prawa majątkowego. W ramach małżeńskiego prawa majątkowego o sytuacji prawnej małżonków jako uczestników obrotu decyduje ustrój majątkowy obowiązujący między małżonkami. Szczególne w tej materii znaczenie mają zasady dotyczące zarządu majątkiem wspólnym, a konkretnie wymóg uzyskania zgody drugiego małżonka na podjęcie czynności określonych w art. 37 k.r.o. Trudności te stają się szczególnie widoczne, gdy na problematykę dotyczącą zarządu majątkiem wspólnym małżonków spojrzymy z szerszego punktu widzenia niż tylko poprzez przepisy kodeksu rodzinnego i opiekuńczego dotyczące zarządu. Wystarczy sięgnąc do kodeksu cywilnego i zawartej w nim definicji gospodarstwa rolnego, a także sporów i wątpliwości co do statusu prawnego gospodarstwa rolnego. Dalsze trudności pojawiają się wraz z stosowaniem innych szczególnych regulacji prawnych, przedmiotem których są zagadnienia dotyczące obrotu nieruchomościami rolnymi, pojęcie gospodarstwa rodzinnego. Tych wszystkich trudności i problemów unikamy w przypadku umownych ustrojów rozdzielności majątkowej i rozdzielności majątkowej z wyrównaniem dorobków.

Równocześnie jednak dostrzegamy nowe zjawisko, jakim jest fakt, że umowne ustroje rozdzielności majątkowej i rozdzielności majątkowej z wyrównaniem dorobków w przypadku, gdy małżonkowie lub jeden z nich prowadzi gospodarstwo 
rolne, nie zapewniają w pełni realizacji zasady, zgodnie z którą każdy z małżonków zarządza samodzielnie swoim majątkiem. Albowiem w sferze stosunków rolnych pojawia się coraz więcej regulacji o charakterze publicznoprawnym, w których sytuacja prawna małżonków jest niezależna od ustroju majątkowego, jaki między nimi istnieje; istotny jest sam fakt pozostawania w związku małżeńskim. Można by zatem postawić pytanie, czy taka tendencja jest prawidłowa? 


\section{Real estate transaction involving spouses}

Key words: marital property system, marriage, legal action

This paper concerns the problem of the real estate transactions in which spouses are involved. Therefore, in the first place the laws that govern marital property systems are examined in order to investigate how the fact of marriage and the choice of a given marital property system influences the legal situation of spouses.

The analysis leads to a conclusion that the legal situation of spouses is determined not so much by the very fact of marriage as by the marital property system that is binding in a given case. Spouses may structure their property relationship in such a way that they retain full independence in taking legal actions concerning the disposal, charging, or acquisition of real estates.

However, at the same time there appear special legal regulations that refer to various public law issues, e.g. diverse forms of support within the Common Agricultural Policy. In these regulations the legal situation of spouses is created in a different way, because the very fact of being married becomes a decisive factor, regardless of the marital property system adopted by the spouses. 